Review Article

\title{
Low Vitamin D and Its Association with Cognitive Impairment and Dementia
}

\author{
Sadia Sultan (D, Uzma Taimuri, Shatha Abdulrzzaq Basnan, Waad Khalid Ai-Orabi, \\ Afaf Awadallah, Fatimah Almowald, and Amira Hazazi
}

College of Applied Medical Sciences, Umm Al-Qura University, Abdiya, Makkah, Saudi Arabia

Correspondence should be addressed to Sadia Sultan; drsaddy2003@yahoo.com

Received 30 July 2019; Revised 3 March 2020; Accepted 26 March 2020; Published 29 April 2020

Academic Editor: F. R. Ferraro

Copyright ( $\odot 2020$ Sadia Sultan et al. This is an open access article distributed under the Creative Commons Attribution License, which permits unrestricted use, distribution, and reproduction in any medium, provided the original work is properly cited.

\begin{abstract}
Vitamin D is a neurosteroid hormone that regulates neurotransmitters and neurotrophins. It has anti-inflammatory, antioxidant, and neuroprotective properties. It increases neurotrophic factors such as nerve growth factor which further promotes brain health. Moreover, it is also helpful in the prevention of amyloid accumulation and promotes amyloid clearance. Emerging evidence suggests its role in the reduction of Alzheimer's disease hallmarks such as amyloid-beta and phosphorylated tau. Many preclinical studies have supported the hypothesis that vitamin D leads to attentional, behavioral problems and cognitive impairment. Crosssectional studies have consistently found that vitamin D levels are significantly low in individuals with Alzheimer's disease and cognitive impairment compared to healthy adults. Longitudinal studies and meta-analysis have also exhibited an association of low vitamin D with cognitive impairment and Alzheimer's disease. Despite such evidence, the causal association cannot be sufficiently answered. In contrast to observational studies, findings from interventional studies have produced mixed results on the role of vitamin D supplementation in the prevention and treatment of cognitive impairment and dementia. The biggest issue of the existing RCTs is their small sample size, lack of consensus over the dose, and age of initiation of vitamin D supplements to prevent cognitive impairment. Therefore, there is a need for large double-blind randomized control trials to assess the benefits of vitamin D supplementation in the prevention and treatment of cognitive impairment.
\end{abstract}

\section{Background}

Vitamin D is a fat-soluble steroid vitamin with a definitive role in bone health. Beyond its role in the regulation of bone health, it also plays an important role in the functioning of other systems such as cardiovascular, endocrine, and nervous systems [1]. Ultraviolet radiation (UVR) is the major source of vitamin $\mathrm{D}$. The two forms of vitamin $\mathrm{D}$ are ergocalciferol (D2) and cholecalciferol (D3). It undergoes two hydroxylation processes, first in the liver by enzyme 25 hydroxylase to produce $25(\mathrm{OH}) \mathrm{D}$ and second in the kidney to produce active form of $1,25(\mathrm{OH}) \mathrm{D}[2,3]$. An estimated one billion people worldwide suffer from hypovitaminosis D. There is no worldwide consensus regarding the cutoff value for definition of vitamin $\mathrm{D}$ deficiency. Typically, vitamin D deficiency is defined as a $25(\mathrm{OH}) \mathrm{D}$ level of less than $50 \mathrm{nmol} / \mathrm{L}$, with severe deficiency defined as less than
$25 \mathrm{nmol} / \mathrm{L}$ and insufficiency between 50 and $75 \mathrm{nmol} / \mathrm{L}$ [4]. Vitamin $\mathrm{D}$ can reach the brain by crossing the blood-brain barrier (BBB) through passive diffusion. The active form, $1,25(\mathrm{OH}) \mathrm{D}$, binds to the vitamin $\mathrm{D}$ receptor (VDR) and influences gene expression. Vitamin $\mathrm{D}$ exerts its action via VDR present in neurons, glial cells of the hippocampus, orbitofrontal-cortex, cingulate, amygdala, and thalamus [5-7]. Its neuroprotective, anti-inflammatory, and antioxidant effect on neurons promotes brain health [8-10]. Vitamin $\mathrm{D}$ promotes the production of neurotrophic factors such as nerve growth factor (NGF). Many studies have consistently reported the increase in neuronal growth in rat hippocampal cell cultures enriched with vitamin $\mathrm{D}[8,9]$. The NGF and other neurotrophic factors promote the survival of both hippocampal and cortical neurons $[10,11]$. Vitamin D is also implicated in regulating the gene expression of various neurotransmitters such as acetylcholine, 
dopamine serotonin, and gamma butyric acid [12, 13]. Vitamin D reduces age-related tau hyperphosphorylation, the formation of amyloid-beta oligomers, increases amyloid clearance, and prevents neuronal death [13]. Although it promotes amyloid phagocytosis and clearance, correlation of serum vitamin D with CSF (cerebrospinal fluid) biomarkers of amyloidosis such as phosphorylated tau and amyloid-beta is, by far, not investigated except very few studies [13]. Nevertheless, vitamin D has also shown its neuroprotective activity by curtailing the glutamate-induced neurotoxicity [13] and upregulating genetic expressing of various proteins required for new synapse formation, thus promoting neurogenesis especially in the hippocampus [14]. Neuroimaging has suggested a positive association between low vitamin D levels, white matter hyperintensities, and enlarged frontal horn of the lateral ventricle [15]. Significant positive correlation of serum $25(\mathrm{OH}) \mathrm{D}$ with total hippocampus volume and disrupted structural connectivity between hippocampus, cortical, and subcortical areas in the right hemisphere was found in patients with mild cognitive impairment [16]. However, small sample size, cross-sectional design, and lack of detailed data on potential covariates (hypertension and diabetes) were the limitations of the study. Furthermore, prospective studies of longer duration exploring neuroimaging outcomes will provide useful insights into potential mechanisms as most neuroimaging studies have been crosssectional resulting in the possibility of reverse causation. This review aims to provide an overview and discussion of the current state of evidence regarding vitamin D and dementia-related outcomes.

\section{Vitamin D and Brain-Evidence through Animal Studies}

Developmental vitamin $\mathrm{D}$ deficiency and inactivated vitamin $\mathrm{D}$ receptor gene affect brain functioning and behavioral outcome in rodents. The studies which support this hypothesis were conducted on mice with prenatal deficiency of vitamin $\mathrm{D}$ and vitamin $\mathrm{D}$ knock-out mice. Rats born to vitamin D3-deficient mothers demonstrated a reduction in the nerve growth factor and glial-derived neurotrophic factor compared to control rats [17]. Similarly, a study on 10week-old rats with transient vitamin $\mathrm{D}$ deficiency during the early developmental stage demonstrated enlarged lateral ventricle volume and reduced nerve growth factor compared to controls [18]. The evidence concerning the impact of vitamin $\mathrm{D}$ deficiency on the behavior of mice which developed later in life is sparse. However, a study investigating the effect of vitamin D-deficient diet for 10 weeks on 20week-old mice reported behavioral and neurochemical changes [19]. Similarly, another study reported a subtle effect on attentional tasks in 16-20-week-old rats with a vitamin $\mathrm{D}$-deficient diet given for 10 weeks compared to control rats [20].

2.1. Evidence through Cross-Sectional and Longitudinal Studies. The association of low vitamin D and global cognitive deficit is established through many cross-sectional and longitudinal studies. Nevertheless, the issue of reverse causality remains to be answered [21]. Table 1 shows a summary of evidence demonstrating an association between serum 25(OH)D, CI, and dementia [9, 21, 22, 23-26]. Many studies have shown an association of low vitamin D with CI at a cross-sectional level although the same studies with longitudinal follow-ups did not replicate the association $[21,23,24]$. All included studies showed a difference in the study population, sample size, participants' age, follow-up time, vitamin $\mathrm{D}$ exposure, method used for estimation for vitamin D, criteria used to diagnose dementia and CI, and methods of assessment of cognition. Most studies adjusted for confounders like age, education, physical activity, diabetes, hypertension, hypercholesteremia, and season. However, most studies did not consider confounders like depression. Four studies [9, 22, 23, 25] found no association between low serum vitamin D levels and CI and dementia in a longitudinal follow-up, whereas two studies [21, 24] found a significant association $(P=0.001)$. However, the studies which found a significant association were smaller in size and duration of follow-up. A Swedish study [22] done on a large sample $(2,841)$ for a longer follow-up (18 years) did not find an association. This study took into account the confounders like common dietary intake of vitamin D, physical activity, and sun exposure. However, repeated blood sampling and dietary assessments improve the precision of exposure information, the study lacked in doing so. Similarly, another American study [25] done on a large sample $(13,044)$ with a long follow-up (20 years) did not report any such association. The previously reported associations between $25(\mathrm{OH}) \mathrm{D}$ concentrations and cognitive impairment may be a result of reverse causation-whereby low $25(\mathrm{OH}) \mathrm{D}$ is a marker of poor health (resulting from those in poor health (e.g., those with cognitive impairment) doing less physical activity and having less sun exposure and thereby having lower vitamin $\mathrm{D}$ concentrations) rather than a causative factor in cognitive impairment and dementia pathogenesis. This study can be considered less susceptible to reverse causation as $25(\mathrm{OH}) \mathrm{D}$ was measured in midlife, and cognitive change was evaluated over 20 years. Another methodological shortcoming compromising the validity of the data is the use of single serum $25(\mathrm{OH}) \mathrm{D}$ measurements taken at baseline to represent long-term exposure in all studies [9, 21, 22, 23-25]. A prospective study with two follow-ups, each at 5 years, conducted to examine the association of dietary and supplemental vitamin $\mathrm{D}$ intake and cognitive decline showed an association between high intake and a slower decline in the cognitive domains of verbal fluency. Those with supplemental intake also exhibited a slower decline in the cognitive domain of verbal fluency although the effect on visual and verbal memory was less in magnitude [26]. Similarly, a study on participants (age 55-67 years) with levels $>25 \mathrm{nmol} / \mathrm{l}$ has demonstrated better verbal fluency and executive functioning both at baseline and at a 10-year follow-up [27].

In contrast to the existing body of literature demonstrating a positive correlation between cognitive function and vitamin D status, Lam et al. [28] reported a negative association between vitamin $\mathrm{D}$ levels and verbal episodic 


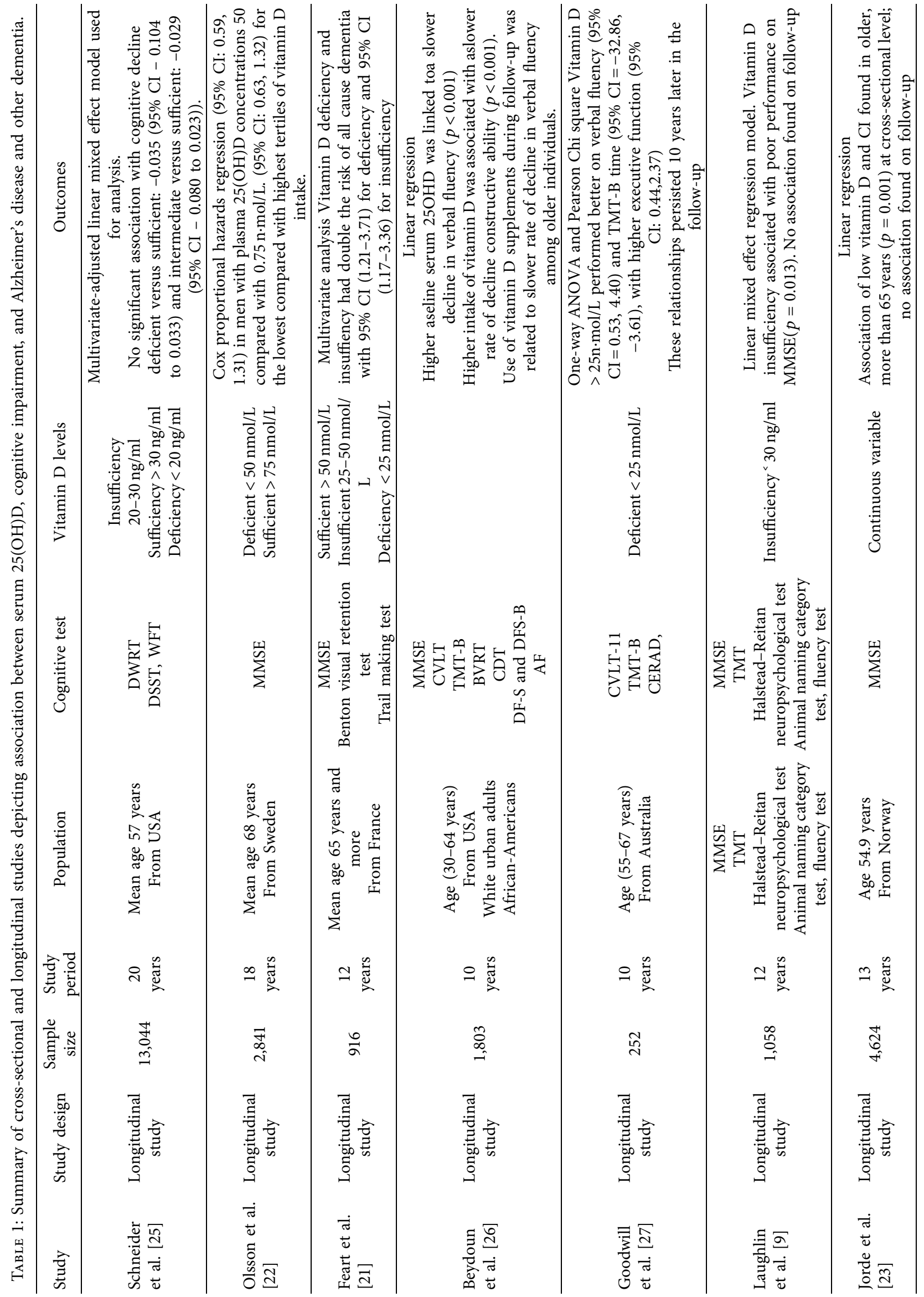




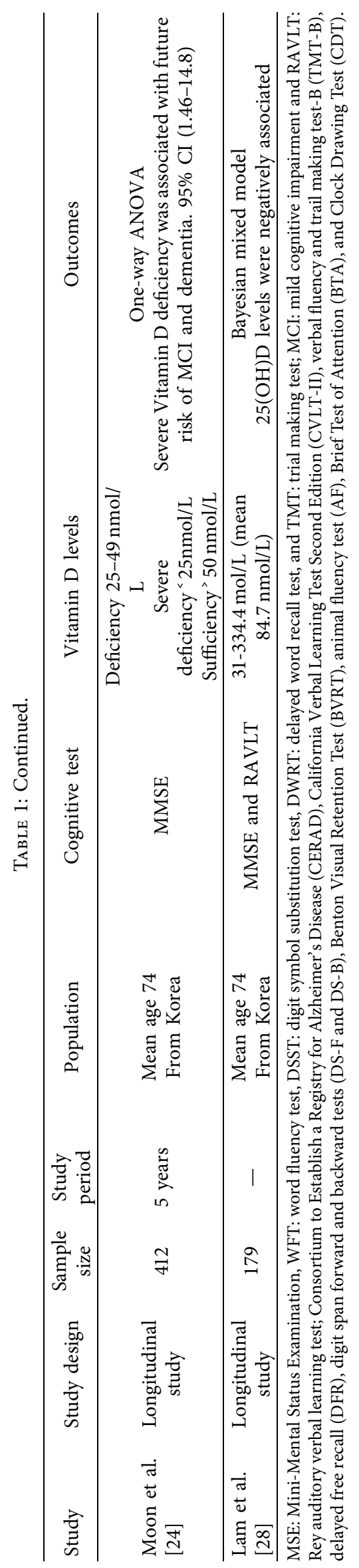




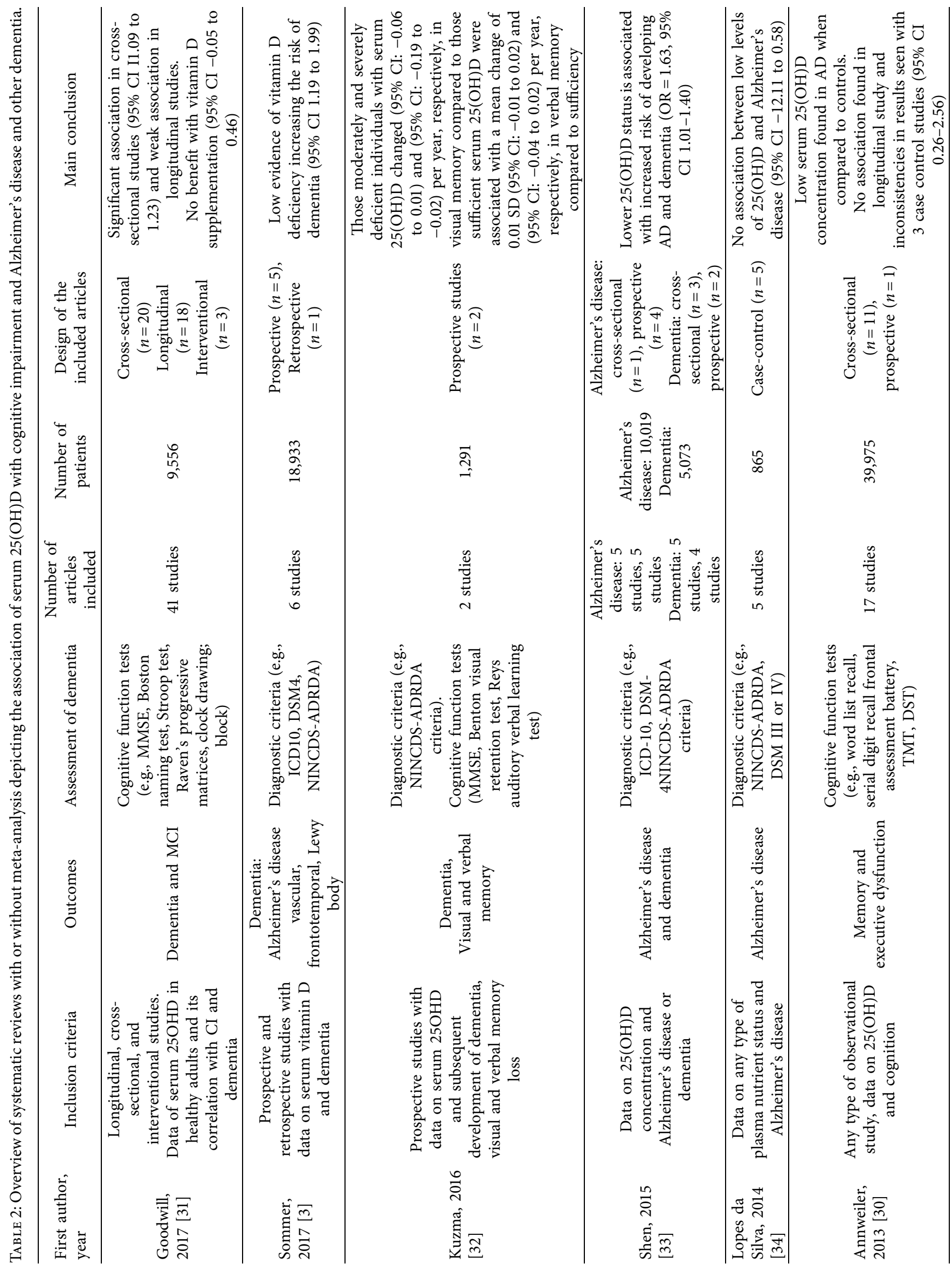




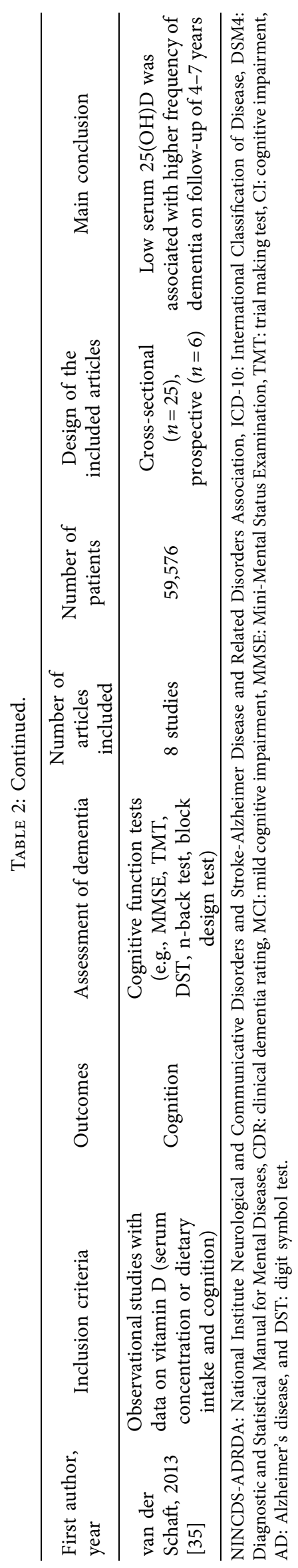


TABLE 3: Summary of findings of vitamin D supplementation and its effect on cognition.

\begin{tabular}{|c|c|c|c|c|c|c|c|}
\hline Author, year & Study design & $\begin{array}{l}\text { Sample } \\
\text { size }\end{array}$ & $\begin{array}{l}\text { Study } \\
\text { period }\end{array}$ & $\begin{array}{c}\text { Population } \\
\text { characteristics }\end{array}$ & Intervention & $\begin{array}{l}\text { Outcome } \\
\text { measures }\end{array}$ & Findings \\
\hline $\begin{array}{l}\text { Przybelski } \\
\text { et al., } 2008 \\
\text { [39] }\end{array}$ & $\begin{array}{l}\text { Prospective } \\
\text { Pre-post } \\
\text { interventional } \\
\text { study }\end{array}$ & 63 & 4 weeks & $\begin{array}{c}\text { USA-nursing } \\
\text { home residents } \\
\text { Intervention } \\
\text { groups } N=25 \\
\text { Mean age }=86.2 \\
\text { females } 68 \% \\
\text { Deficiency defined } \\
\text { as } 25(\mathrm{OH}) \mathrm{D} \\
<25 \mathrm{ng} / \mathrm{mL} \\
\text { Comparison group } \\
N=38 \\
\text { Mean age }=87.4 \text {, } \\
\text { female } 78.9 \% \\
\text { Serum } 25(\mathrm{OH}) \mathrm{D} \\
<25 \mathrm{ng} / \mathrm{mL}\end{array}$ & $\begin{array}{l}\text { Unblinded study } \\
\text { Intervention group } \\
50,000 \text { IU of Vit D2, } 3 \\
\text { times per week for } \\
\text { duration of } 4 \text { weeks } \\
\text { Comparison group } \\
\text { No placebo } \\
\text { No supplementation }\end{array}$ & $\begin{array}{c}\text { Cognitive test } \\
\text { Clock drawing } \\
\text { test } \\
\text { Semantic } \\
\text { fluency test }\end{array}$ & $\begin{array}{l}\text { No significant } \\
\text { difference in } \\
\text { cognitive outcome } \\
\text { measures, although } \\
\text { significant change } \\
(p=0.0001) \text { in } \\
\text { serum } 25(\mathrm{OH}) \mathrm{D} \\
\text { levels from } 17.3 \text { to } \\
63.8 \mathrm{ng} / \mathrm{mL}\end{array}$ \\
\hline $\begin{array}{l}\text { Stein, et al., } \\
2011 \text { [36] }\end{array}$ & $\begin{array}{l}\text { Randomized } \\
\text { controlled trial }\end{array}$ & 32 & 6 weeks & $\begin{array}{c}\text { Australia- } \\
\text { community } \\
\text { dwellers with mild- } \\
\text { to-moderate } \\
\text { dementia } \\
\text { High dose group } \\
N=16 \\
\text { Low dose group } \\
N=16 \\
\text { Mean age } 79 \\
\text { Females }=50 \%\end{array}$ & $\begin{array}{c}\text { First } 1,000 \text { IU Vit D2 } \\
\text { daily for } 8 \text { weeks } \\
\text { Then, 6,000 IU Vit D2 } \\
\text { daily for } 8 \\
\text { Intranasal insulin } \\
\text { (60 IU/4 times/day) and } \\
50 \% \text { randomized to } \\
\text { placebo } \\
\text { Comparison group } \\
1,000 \text { IU Vit D2 daily } \\
\text { for } 16 \text { weeks } \\
\text { Finally, 50\% } \\
\text { randomized to } \\
\text { Intranasal insulin } \\
\text { (60 IU4 times/day) and } \\
50 \% \text { randomized to } \\
\text { placebo for } 2 \text { days }\end{array}$ & $\begin{array}{l}\text { Alzheimer } \\
\text { assessment } \\
\text { scale-cognitive } \\
\text { subscale (ADAS } \\
\text { memory scale- } \\
\text { revised logical } \\
\text { memory (WSM- } \\
\text { RLM) }\end{array}$ & $\begin{array}{l}\text { Minitab release } 13.1 \\
\text { used to calculate CI. } \\
\text { Significant median } \\
\text { increase in serum } \\
25(\mathrm{OH}) \mathrm{D} \\
\text { concentrations in the } \\
\text { high dose group } \\
\text { (187 nM) } \\
\text { No significant } \\
\text { differences } \\
\text { ( } p=0.02) \text { on any of } \\
\text { the outcome } \\
\text { measures) between } \\
\text { groups. ADAS-Cog } \\
\text { (95\% CI-5 to 3) } \\
\text { WSM-RLM (95\% CI } \\
-1 \text { to 3) }\end{array}$ \\
\hline $\begin{array}{l}\text { Annweiler, } \\
\text { et al., } 2012 \\
{[40]}\end{array}$ & $\begin{array}{c}\text { Prospective } \\
\text { Pre-post } \\
\text { interventiona } 1 \\
\text { study }\end{array}$ & 44 & $\begin{array}{c}16 \\
\text { months }\end{array}$ & $\begin{array}{c}\begin{array}{c}\text { France-outpatient } \\
\text { from memory } \\
\text { clinic }\end{array} \\
\text { Intervention group } \\
N=20 \\
\text { Mean age } 81.9 \\
\text { females }=55 \% \\
\text { Comparison group } \\
N=24 \\
\text { Mean age } 75 . \\
\text { Females }=54.2 \% \\
\end{array}$ & $\begin{array}{c}\text { Unblinded } \\
\text { Unrandomized } \\
\text { intervention } \\
\text { group }=800 \mathrm{IU} / \text { day or } \\
1,000,000 \mathrm{IU} \text { of Vit D3/ } \\
\text { month comparison } \\
\text { group }=\text { no placebo }\end{array}$ & $\begin{array}{l}\text { MMSE } \\
\text { Frontal } \\
\text { assessment } \\
\text { battery } \\
\text { Cognitive } \\
\text { assessment } \\
\text { battery }\end{array}$ & $\begin{array}{c}\text { Over the 3-year } \\
\text { period, MMSE } \\
\text { scores increased in } \\
\text { both groups } \\
(p<0.001) \text {, although } \\
\text { change over time was } \\
\text { not significantly } \\
\text { different between the } \\
\text { groups }\end{array}$ \\
\hline $\begin{array}{l}\text { Owusu } \\
\text { et al., } 2018 \\
\text { [37] }\end{array}$ & $\begin{array}{l}\text { Randomized } \\
\text { controlled trial }\end{array}$ & 390 & 3 years & $\begin{array}{c}\text { USA-healthy } \\
\text { African-American } \\
\text { postmenopausal } \\
\text { women } \\
\text { Intervention group } \\
N=130 \\
\text { Mean age } 67.8 \\
\text { Control group } \\
N=130\end{array}$ & $\begin{array}{c}\text { Double-blind } \\
\text { randomized placebo- } \\
\text { controlled trial } \\
\text { Intervention Vit D3 } \\
(2,400 \mathrm{IU}-3,600 \mathrm{IU} \text { or } \\
4,800 \mathrm{IU} / \text { day }) \text { which } \\
\text { maintained } 25(\mathrm{OH}) \mathrm{D} \\
\text { level of } 30 \mathrm{ng} / \mathrm{mL} \\
\text { Control group Placebo } \\
\text { follow-up of } 3 \text { years }\end{array}$ & $\begin{array}{c}\text { MMSE } \\
\text { Every } 6 \text { months } \\
<27 \\
\text { Considered as } \\
\text { mild MCI }\end{array}$ & $\begin{array}{l}\text { No difference in } \\
\text { cognition over time } \\
\text { between older } \\
\text { African-American } \\
\text { women with serum } \\
\text { concentrations of } \\
25(\mathrm{OH}) \mathrm{D} \text { of } 30 \mathrm{ng} / \\
\mathrm{mL} \text { and greater than } \\
\text { those taking placebo }\end{array}$ \\
\hline
\end{tabular}


TABLE 3: Continued.

\begin{tabular}{|c|c|c|c|c|c|c|c|}
\hline Author, year & Study design & $\begin{array}{c}\text { Sample } \\
\text { size }\end{array}$ & $\begin{array}{l}\text { Study } \\
\text { period }\end{array}$ & $\begin{array}{c}\text { Population } \\
\text { characteristics }\end{array}$ & Intervention & $\begin{array}{l}\text { Outcome } \\
\text { measures }\end{array}$ & Findings \\
\hline $\begin{array}{l}\text { Petterson } \\
\text { Trial, } 2017 \\
{[38]}\end{array}$ & $\begin{array}{l}\text { Randomized } \\
\text { controlled trial }\end{array}$ & 82 & $\begin{array}{c}18 \\
\text { weeks }\end{array}$ & $\begin{array}{c}\text { Canada-healthy } \\
\text { adults } \\
\text { High dose group } \\
\quad N=42 \\
\text { Mean age }=56.7 \\
\text { Low dose group } \\
N=40 \\
\text { Mean age }=52.6 \\
\text { Females }=65 \%\end{array}$ & $\begin{array}{c}\text { Randomized and } \\
\text { blinded to high dose } \\
\text { High dose group Vit D3 } \\
\text { 4,000 IU/day } \\
\text { Low } \\
\text { Dose group Vit D3 } \\
400 \mathrm{IU} / \text { day }\end{array}$ & $\begin{array}{c}\text { Pattern } \\
\text { recognition } \\
\text { memory task } \\
\text { Paired associate } \\
\text { learning task }\end{array}$ & $\begin{array}{c}\text { Visual memory } \\
\text { benefit with high } \\
\text { dose }(p=0.005) \text { in } \\
\text { those who are } \\
\text { insufficient } \\
(<75 \mathrm{nmol} / \mathrm{L}) \\
\text { No change in verbal } \\
\text { memory }\end{array}$ \\
\hline
\end{tabular}

memory. In a prospective (3-year follow-up), populationbased study of older adults aged $85+$, it was found that both low and high season-specific quartiles of $25(\mathrm{OH}) \mathrm{D}$ were associated with higher odds of prevalent cognitive impairment (assessed by MMSE), poorer attention reaction times/ processing speed and focused attention/concentration, and greater attention fluctuation [29].

2.2. Evidence through Meta-Analysis and Systematic Review. Several systematic reviews and meta-analysis of cross-sectional studies, case-control studies, and observation prospective studies have suggested an association between low vitamin $\mathrm{D}$, cognitive impairment, and dementia. Moreover, a meta-analysis on vitamin $\mathrm{D}$ levels and specific cognitive domains have suggested a strong association between low vitamin $\mathrm{D}$ and a range of executive dysfunction, such as impaired processing speed, mental shifting, and information updating. Only a modest association was noted with episodic memory [30]. Several such systematic reviews and metaanalysis in the last 6 years are depicted in Table 2 [30-34].

2.3. Vitamin D Supplementation and Cognition. Five studies have investigated the effects of vitamin D supplementation on cognitive outcomes in elderly individuals (see Table 3); three were RCT's [36-38] and two had pre-post study design $[8,37]$. Overall, three studies found that vitamin D supplementation did not improve either cognitive outcomes $[36,38,39]$ or reduce the risk of dementia/MCI compared to controls. A prospective pre-post interventional study [39] on nursing home residents with a mean age (86 years) reported no significant change in cognitive outcome with oral vitamin D2 (50,000 IU 3 times/week) for 4 weeks. On the contrary, another prospective pre-post interventional study [37], which included 80-year-old subjects from memory clinic, found that those who received oral vitamin D3 supplementation (800 IU per day or 100,000 IU per month) experienced improved global cognition and executive functioning abilities over a 16-month follow-up period compared to controls [40]. Nevertheless, the pre-post design (without randomization) of the study and small sample size and shorter duration of treatment limit the exploration of cognitive effect of vitamin D. A randomized trial [38] found that visual memory improved in the high dose group $(4,000 \mathrm{IU}$ per day for 18 weeks of oral vitamin D supplementation) when compared to the low dose group (400 IU per day) in healthy adults, although verbal memory and other cognitive domains did not improve. On the contrary, Stien et al. [36] reported no significant change in cognition with higher doses of vitamin $\mathrm{D}$ followed by intranasal insulin (nasal insulin improves cognition, and vitamin $\mathrm{D}$ increases insulin receptor expression) when compared to lower dose of vitamin D and intranasal insulin in subjects diagnosed with mild-to-moderate AD. A more recent double-blind, randomized, placebo-controlled trial showed no significant difference in cognition over time (3 years) according to the MMSE score (assessed every 6 months) between older postmenopausal African-American women who took vitamin D (orally in doses of 2,400, 3,600, and 4,800 which maintained serum level of $>30 \mathrm{ng} / \mathrm{mL}$ ) than those who did not [37]. However, methodological weaknesses such as small sample sizes $[36,38,39]$, short follow-up periods [36, 38, 39], and lack of participant randomization $[39,40]$, as well as heterogeneous doses of vitamin D supplementation and baseline vitamin $\mathrm{D}$ levels make it difficult to interpret the results of the interventional studies. Another limitation found in most studies was the use of MMSE for cognitive testing. This test is best used as a screening tool and not for diagnosis. There is no clear idea of when vitamin $\mathrm{D}$ is most effective in the pathogenesis of cognitive decline and particularly the advent of AD. Therefore, the supplementation of vitamin $\mathrm{D}$ after the advent of $\mathrm{CI}$ or $\mathrm{AD}$ might not have helped the already existing neurological insult which could have been the reason for the failure of such a treatment. Larger trials over a longer period in patients at risk for, but has not yet progressed to cognitive decline or dementia, may be more capable of demonstrating an impact. Identifying such individuals using CSF biomarkers such as amyloid-beta and phosphorylated tau may help. Future studies directed towards finding the effect of vitamin $\mathrm{D}$ on biomarkers of $\mathrm{AD}$ would further clarify the role of vitamin $\mathrm{D}$ and its disease-modifying effect. Pharmacogenomic studies to identify the individuals who could benefit from such a therapy may further help.

\section{Conclusion}

Evidence from animal and cellular studies suggests that vitamin $\mathrm{D}$ has multiple functions throughout the central nervous system and could be implicated in the prevention 
and treatment of disorders such as dementia and AD. Crosssectional and case-control studies confirm that vitamin D concentrations are lower in individuals with cognitive impairment and dementia although reverse causality remains a possibility. Few longitudinal studies have found that low vitamin $\mathrm{D}$ concentrations are associated with an increased risk of cognitive decline, all-cause dementia, and $\mathrm{AD}$, but those with a bigger sample size and longer (18-20 years) follow-up time did not find such an association. Future neuroimaging studies may uncover a link with specific abnormalities that could explain the observed associations between vitamin $\mathrm{D}$ concentrations and dementia-related disorders. Clinical trials investigating the effect of vitamin D supplementation on cognitive outcomes have produced mixed findings; however, a variety of methodological weaknesses limit the interpretability of these findings. Lack of consensus over the exact dosage of vitamin $\mathrm{D}$ to be used and optimal age of treatment initiation of individuals at risk remains unidentified. Furthermore, large double-blind, randomized, placebo-controlled trials with appropriate dosage and duration may provide conclusive results. Taken together, this body of evidence suggests that vitamin D may be a new paradigm for therapy in the prevention and treatment of dementia and $\mathrm{AD}$. Although vitamin $\mathrm{D}$ may be considered as a modifiable risk factor, the causal relationship between vitamin D deficiency and CI so far remains inconclusive.

\section{Abbreviations}

$\begin{array}{ll}\text { 25(OH)D: } & \text { 25 hydroxyvitamin D } \\ \text { A } \beta: & \text { Amyloid-beta } \\ \text { AD: } & \text { Alzheimer's disease } \\ \text { AMSTAR: } & \text { Assessing the methodological quality of } \\ & \text { systematic reviews } \\ \text { BBB: } & \text { Blood-brain barrier } \\ \text { BDNF: } & \text { Brain-derived neurotrophic factor } \\ \text { CDR: } & \text { Clinical dementia rating } \\ \text { CI: } & \text { Cognitive impairment } \\ \text { CKD: } & \text { Chronic kidney disease } \\ \text { CSF: } & \text { Cerebral spinal fluid } \\ \text { DSM4: } & \text { Diagnostic and Statistical Manual for Mental } \\ & \text { Disease } \\ \text { DSST: } & \text { Digit symbol substitution test } \\ \text { DST: } & \text { Digit symbol test } \\ \text { DWRT: } & \text { Delayed word recall test } \\ \text { GM: } & \text { Grey matter } \\ \text { HPV: } & \text { Hippocampal volume } \\ \text { ICD: } & \text { International Classification of Disease } \\ \text { ICV: } & \text { Intracranial volumes } \\ \text { IOM: } & \text { Institute of medicine } \\ \text { LTP: } & \text { Long-term potentiation } \\ \text { MCI: } & \text { Mild cognitive impairment } \\ \text { MMSE: } & \text { Mini-Mental Status Examination } \\ \text { NGF: } & \text { Nerve growth factor } \\ \text { NINCDS- } & \text { National institute neurological and } \\ \text { ADRDA: } & \text { communicative disorders and stroke- } \\ & \text { Alzheimer disease and related disorders } \\ \text { NMDA: } & \text { N-Methyl d-aspartate } \\ & \end{array}$

RCT: $\quad$ Randomized controlled trials

RDA: Recommended daily allowances

TMT: $\quad$ Trial making test

UVR: Ultraviolet radiation

VDR: Vitamin D receptor

WFT: $\quad$ Word fluency test

WM: White matter

WMA: White matter abnormalities

WMH: White matter hyperintensities.

\section{Conflicts of Interest}

The authors declare that they have no conflicts of interest.

\section{Authors' Contributions}

Dr. S. Sultan, MD, substantially contributed to conception or design of the work, finally approved the version to be published, and was responsible for agreement to be accountable for all aspects of the work in ensuring that questions related to the accuracy or integrity of any part of the work are appropriately investigated and resolved. Miss Uzma Taimuri, Miss SA Basnan, Miss W K A Orabi, Miss A Awadallah, Miss F Almowald, and A Hazazi substantially contributed to conception and design of the work. All authors read and approved the manuscript.

\section{References}

[1] B. Hooshmand, J. Lökk, A. Solomon et al., "Vitamin D in relation to cognitive impairment, cerebrospinal fluid biomarkers, and brain volumes," The Journals of Gerontology: Series A, vol. 69, no. 9, pp. 1132-1138, 2014.

[2] V. Landel, C. Annweiler, P. Millet, M. Morello, and F. Féron, "Vitamin D, cognition and Alzheimer's disease: the therapeutic benefit is in the D-tails," Journal of Alzheimer's Disease, vol. 53, no. 2, pp. 419-444, 2016.

[3] I. Sommer, U. Griebler, C. Kien et al., "Vitamin D deficiency as a risk factor for dementia: a systematic review and metaanalysis," BMC Geriatrics, vol. 17, no. 1, p. 16, 2017.

[4] M. F. Holick, "Vitamin D deficiency," New England Journal of Medicine, vol. 357, no. 3, pp. 266-281, 2007.

[5] C. Annweiler, E. Dursun, F. Féron et al., "Vitamin D and cognition in older adults: international consensus guidelines," Gériatrie et Psychologie Neuropsychiatrie du Viellissement, vol. 14, no. 3, pp. 265-273, 2016.

[6] E. Lukaszyk, K. Bien-Barkowska, and B. Bien, "Cognitive functioning of geriatric patients: is hypovitaminosis D the next marker of cognitive dysfunction and dementia?" $\mathrm{Nu}$ trients, vol. 10, no. 8, p. 1104, 2018.

[7] T. J. Littlejohns, K. Kos, W. E. Henley, E. Kuźma, and D. J. Llewellyn, "Vitamin D and dementia," The Journal of Prevention of Alzheimer's Disease, vol. 3, no. 3, pp. 43-52, 2016.

[8] E. M. Brouwer-Brolsma and L. C. P. G. M. de Groot, "Vitamin $\mathrm{D}$ and cognition in older adults," Current Opinion in Clinical Nutrition and Metabolic Care, vol. 18, no. 1, pp. 11-16, 2015.

[9] G. A. Laughlin, D. Kritz-Silverstein, J. Bergstrom et al., "Vitamin D insufficiency and cognitive function trajectories in older adults: the rancho bernardo study," Journal of Alzheimer's Disease, vol. 58, no. 3, pp. 871-883, 2017.

[10] C. Annweiler, "Vitamin D in dementia prevention," Annals of the New York Academy of Sciences, vol. 1367, no. 1, pp. 57-63, 2016. 
[11] I. Karakis, M. P. Pase, A. Beiser et al., "Association of serum vitamin $\mathrm{D}$ with the risk of incident dementia and subclinical indices of brain aging: the framingham heart study," Journal of Alzheimer's Disease, vol. 51, no. 2, pp. 451-461, 2016.

[12] I. Anjum, S. S. Jaffery, M. Fayyaz, Z. Samoo, and S. Anjum, "The role of vitamin D in brain health: a mini literature review," Cureus, vol. 10, no. 7, Article ID e2960, 2018.

[13] R. Moretti, M. E. Morelli, and P. Caruso, "Vitamin D in neurological diseases: a rationale for a pathogenic impact," International Journal of Molecular Sciences, vol. 19, no. 8, p. 2245, 2018.

[14] C. S. Latimer, L. D. Brewer, J. L. Searcy et al., "Vitamin D prevents cognitive decline and enhances hippocampal synaptic function in aging rats," Proceedings of the National Academy of Sciences, vol. 111, no. 41, pp. E4359-E4366, 2014.

[15] C. Annweiler, T. Annweiler, R. Bartha, F. R. Herrmann, R. Camicioli, and O. Beauchet, "Vitamin D and white matter abnormalities in older adults: a cross-sectional neuroimaging study," European Journal of Neurology, vol. 21, no. 12, pp. 1436-e95, 2014.

[16] M. Al-Amin, D. Bradford, R. K. P. Sullivan et al., "Vitamin D deficiency is associated with reduced hippocampal volume and disrupted structural connectivity in patients with mild cognitive impairment," Human Brain Mapping, vol. 40, no. 2, pp. 394-406, 2019.

[17] D. Eyles, J. Brown, A. Mackay-Sim, J. McGrath, and F. Feron, "Vitamin D3 and brain development," Neuroscience, vol. 118, no. 3, pp. 641-653, 2003.

[18] F. Féron, T. H. J. Burne, J. Brown et al., "Developmental vitamin D3 deficiency alters the adult rat brain," Brain Research Bulletin, vol. 65, no. 2, pp. 141-148, 2005.

[19] N. J. Groves, J. P. Kesby, D. W. Eyles, J. J. McGrath, A. Mackay-Sim, and T. H. J. Burne, "Adult vitamin D deficiency leads to behavioural and brain neurochemical alterations in C57BL/6J and BALB/c mice," Behavioural Brain Research, vol. 241, pp. 120-131, 2013.

[20] J. H. Byrne, M. Voogt, K. M. Turner et al., "The impact of adult vitamin $\mathrm{D}$ deficiency on behaviour and brain function in male Sprague-Dawley rats," PLoS One, vol. 8, no. 8, Article ID e71593, 2013.

[21] C. Feart, C. Helmer, B. Merle et al., "Associations of lower vitamin $\mathrm{D}$ concentrations with cognitive decline and longterm risk of dementia and Alzheimer's disease in older adults," Alzheimer's \& Dementia, vol. 13, no. 11, pp. 1207-1216, 2017.

[22] E. Olsson, L. Byberg, B. Karlström et al., "Vitamin D is not associated with incident dementia or cognitive impairment: an 18-y follow-up study in community-living old men," The American Journal of Clinical Nutrition, vol. 105, no. 4, pp. 936-943, 2017.

[23] R. Jorde, E. B. Mathiesen, S. Rogne et al., "Vitamin D and cognitive function: the tromso study," J Neurol Sci, vol. 355, no. 1-2, pp. 155-161, 2015.

[24] J. H. Moon, S. Lim, J. W. Han et al., "Serum 25-hydroxy vitamin $\mathrm{D}$ level and the risk of mild cognitive impairment and dementia: the Korean longitudinal study on health and aging (KLoSHA)," Clinical Endocrinology, vol. 83, no. 1, pp. 36-42, 2015.

[25] A. L. C. Schneider, D. Zhao, P. L. Lutsey et al., "Serum vitamin $\mathrm{D}$ concentrations and cognitive change over 20 Years: the atherosclerosis risk in communities neurocognitive study," Neuroepidemiology, vol. 51, no. 3-4, p. 131, 2018.

[26] M. A. Beydoun, S. Hossain, M. T. Fanelli-Kuczmarski et al., "Vitamin D status and intakes and their association with cognitive trajectory in a longitudinal study of urban adults," The Journal of Clinical Endocrinology \& Metabolism, vol. 103, no. 4, pp. 1654-1668, 2018.

[27] A. M. Goodwill, S. Campbell, S. Simpson et al., "Vitamin D status is associated with executive function a decade later: data from the Women's Healthy Ageing Project," Maturitas, vol. 107, pp. 56-62, 2018.

[28] V. Lam, M. A. Albrecht, R. Takechi et al., "Serum 25-hydroxy vitamin $\mathrm{D}$ is associated with reduced verbal episodic memory in healthy, middle-aged and older adults," European Journal of Nutrition, vol. 55, no. 4, pp. 1503-1513, 2016.

[29] A. Granic, T. R. Hill, T. B. Kirkwood, K. Davies, J. Collerton et al., "Serum 25-hydroxyvitamin D and cognitive decline in the very old: the Newcastle 85+ Study," European Journal of Neurology, vol. 22, no. 1, pp. e106-e107, 2015.

[30] C. Annweiler, M. Montero-Odasso, D. J. Llewellyn, S. Richard-Devantoy, G. Duque, and O. Beauchet, "Metaanalysis of memory and executive dysfunctions in relation to vitamin D," Journal of Alzheimer's Disease, vol. 37, no. 1, pp. 147-171, 2013.

[31] A. M. Goodwill and C. Szoeke, "A systematic review and meta-analysis of the effect of low vitamin D on cognition," Journal of the American Geriatrics Society, vol. 65, no. 10, pp. 2161-2168, 2017.

[32] E. Kuzma, M. Soni, T. J. Littlejohns et al., "Vitamin D and memory decline: two population-based prospective studies," Journal of Alzheimer's Disease, vol. 50, no. 4, pp. 1099-1108, 2016.

[33] L. Shen and H. F. Ji, "Vitamin D deficiency is associated with increased risk of Alzheimer's disease and dementia: evidence from meta-analysis," Nutrition Journal, vol. 14, no. 1, p. 76, 2015.

[34] S. Lopes da Silva, B. Vellas, S. Elemans et al., "Plasma nutrient status of patients with Alzheimer's disease: systematic review and meta-analysis," Alzheimer's \& Dementia, vol. 10, no. 4, pp. 485-502, 2014.

[35] J. Van der Schaft, H. L. Koek, E. Dijkstra, H. J. J. Verhaar, Y. T. van der Schouw, and M. H. Emmelot-Vonk, "The association between vitamin $\mathrm{D}$ and cognition: a systematic review," Ageing Research Reviews, vol. 12, no. 4, pp. 10131023, 2013.

[36] M. S. Stein, S. C. Scherer, K. S. Ladd, and L. C. Harrison, "A randomized controlled trial of high-dose vitamin D2 followed by intranasal insulin in Alzheimer's disease," Journal of Alzheimer's Disease, vol. 26, no. 3, pp. 477-484, 2011.

[37] J. E. Owusu, S. Islam, S. S. Katumuluwa et al., "Cognition and vitamin $\mathrm{D}$ in older African-American women- physical performance and osteoporosis prevention with vitamin $\mathrm{D}$ in older african Americans trial and dementia," Journal of the American Geriatrics Society, vol. 67, no. 1, pp. 81-86, 2019.

[38] J. A. Pettersen, "Does high dose vitamin D supplementation enhance cognition?: a randomized trial in healthy adults," Experimental Gerontology, vol. 90, pp. 90-97, 2017.

[39] R. Przybelski, S. Agrawal, D. Krueger, J. A. Engelke, F. Walbrun, and N. Binkley, "Rapid correction of low vitamin D status in nursing home residents," Osteoporosis International, vol. 19, no. 11, pp. 1621-1628, 2008.

[40] C. Annweiler, B. Fantino, J. Gautier, M. Beaudenon, S. Thiery, and O. Beauchet, "Cognitive effects of vitamin D supplementation in older outpatients visiting a memory clinic: a prepost study," Journal of the American Geriatrics Society, vol. 60, no. 4, pp. 793-795, 2012. 